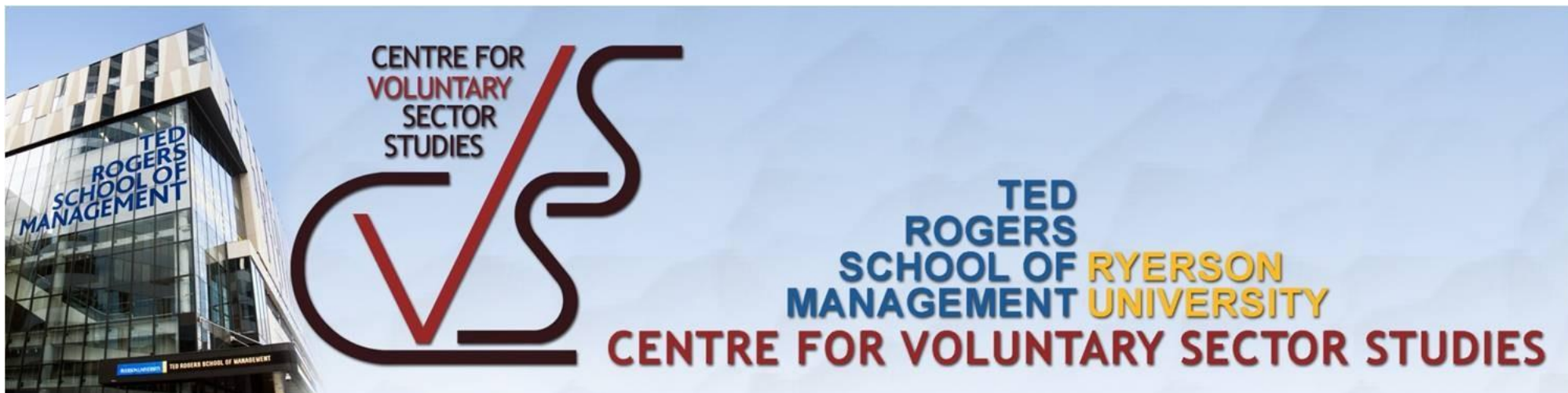

\title{
Social Return on Investment at Inspirations Studio
}

\author{
Agnes Meinhard PhD \\ Centre for Voluntary Sector Studies \\ Ryerson University \\ Christina Butty \\ Centre for Voluntary Sector Studies \\ Ryerson University \\ Theresa Morin \\ Inspirations Studio
}

Working Paper Series

2014(3)

350 Victoria Street

Toronto, Ontario M5B 2K3

Tel: 416-979-5000 x 6739/Fax: 416-9795124

cvss@ ryerson.ca

http://www.ryerson.ca/cvss/working_papers 


\section{Acknowledgements}

This research is part of a larger project headed by Jack Quarter and funded by the Social Sciences and Humanities Research Council of Canada. We gratefully acknowledge the helpful comments by Jack Quarter, Laurie Mook and Sherida Ryan. 


\section{Introduction}

Inspirations Studio is a "micro-business incubator for low income women who have been impacted by poverty, homelessness, trauma and mental health issues (About Us, n.d)." The Toronto nonprofit social enterprise helps its members 'learn pottery and business skills so that they can earn income' (About Us, n.d). The women members are self-employed, operating independent micro-businesses; at the studio they learn to make pottery and to run a business, sell the pottery they make, and use the income from the sales to better their lives. Although the women retain most of the earnings from the sale of their Inpirations-made pottery, they also pay the studio a fee for use of its facilities and clay materials. Because it is business with a social purpose - to teach disadvantaged women to make and sell pottery and by so doing, enhance their well-being, and commercial - to create and sell quality products - it is considered to be a social enterprise.

A recent case study of the organization found that, for a relatively low budget operation, Inspirations Studio generates enough benefits to its stakeholders to make it well worth the investment in the social enterprise (Meinhard, Lok \& O'Connor, 2014). The case study used a systems-analytic, value-proposition framework to identify the elements and relationships necessary to create and deliver value to the stakeholders of the organization.

This paper attempts to calculate as accurately as possible the social return on investment (SROI). This is not an easy task, as many of the benefits are neither immediately evident nor directly measurable.

Moreover, as yet, the studio does not cover its operating costs, and relies somewhat on financial support from its parent service agency, Sistering (a drop-in centre offering practical and emotional support to women to enable them to gain greater control of their lives (About Us, n.d)), from which the studio is semi-autonomous. The studio also relies on government grants, and donations from various funders. Given that the studio is not self-sustaining, a simple calculation of financial return on investment is not the ideal way in which to gauge the true value of the enterprise. By calculating the social return on investment, this paper attempts to demonstrate how Inspiration Studio adds value to the lives of the studio members as well as to societal stakeholders. After outlining the general difficulties encountered in calculating SROI, this paper points out the specifics as relates to this social enterprise.

\section{Calculating SROI}

In a business enterprise it is relatively easy to calculate the return on investment by subtracting the enterprise's costs from its earned income. This can be done on a yearly basis, or if there is a large initial investment, it can be calculated over a specified number of years. If the earned income is greater than the costs, then the business is making money, if the earned income is less, then it is losing money and the business will most likely fail. With a nonprofit social enterprise, in which the social goals are as important as the financial goals, the calculations are not so straight-forward. Unless the social enterprise earns enough to cover all of its costs, the calculation of return on investment must cover social benefits as well. As pointed out in the opening chapter, this is a difficult process that involves estimating and using proxies. 
Unlike many SROI projects such as providing employment or employment training to large numbers of "hard to employ" citizens, where the key measure of success can be determined from macro-economic indicators such as reduced unemployment and its benefits to society, or even to a particular community, in this study the impact on macro-economic indicators is negligible. Therefore what we actually calculate is cost savings on an individual level. For example, if the program results in fewer hospitalizations, then this savings is subtracted from the actual costs to the benefactors. If the benefits exceed the costs, then there is a net value to society, if the costs exceed the benefits, the question arises as to whether it is still worth whatever cost remains to cover the truly intangibles such as contentment and enjoyment of life.

We based our calculation of SROI on the following: a) actual return on investment; b) dollar value of measurable social benefits as a result of participation in Inspirations Studio; c) estimated dollar value to the community and society as a result of the existence of Inspirations Studio.

\subsection{Actual Return on Investment}

Using the financial statements provided by Inspirations Studio for the years 2010, 2011, 2012, 2013, we calculated: a) the average costs over the four years of running the studio, which included rent and affiliated expenses, salaries and materials; b) the four-year average earned coming to the studio, made up of the portion of the sales revenue accruing to the studio plus the clay reclamation. Subtracting the former from the latter, we calculated net gain/loss.

\subsection{Dollar Value of Measurable Health/Social Benefits to Participants}

In order to measure the dollar value of the health benefits that the women gain from being members at Inspirations, we first had to determine the improvements in their health. As this study was not designed as pre/post intervention design, nor did we have independent data on their health behaviours, we had to rely on subjective reports by the women. To this end we designed a questionnaire in which they were asked about partaking in certain health activities and behaviours before they joined Inspirations, and currently. For example, they were asked how often they used emergency services before joining Inspirations, and how often they do so currently. For non-easily quantifiable questions, we just asked them whether or not they had experienced changes. For example, they were asked whether they had experienced changes in weight, eating habits and sleeping habits. The survey consisted of 29 behavioural items measuring their health and social well-being as well as some demographic questions relating to age, education, and length and extent of participation in Inspirations program. We compared their before and after responses to determine behavioural changes. Sixteen of the 29 members of Inspirations responded to the questionnaire $(55 \%$ response rate), with 12 completions. For most of the incomplete questionnaires the omitted questions were the demographic ones, which were the last few questions of the questionnaire. One of the weaknesses of this type of study is that it relies on retrospective recall and subjective evaluations. Therefore, in the absence of a pre-post experimental design it is difficult to attribute all the changes to Inspirations Studio, even if the subjective reporting is accurate.

We also conducted key informant and focus group interviews with staff and members of Inspirations Studio (for a full description of these interviews and their results, please refer to Meinhard et al. 2014). These research instruments received approval from the Ryerson Ethics 
Board. The survey was anonymous and interviews were confidential. Through these various instruments we determined whether the women experienced: a) enhanced social well-being, b) improved physical health, c) improved mental health, d) increased human capital (education, skills, earning capacity) and e) greater social involvement. The financial value of several of these improvements could be measured quite accurately using cost tables for medical and social services prepared by government.

\subsection{Estimated dollar value to the community and society}

As some of the social gains are more difficult to translate directly into dollars, we estimated their impact on community and society by combing the literature to find some proxy measures. We tried to calculate the impact on the community of greater cash flow resulting from the increased earnings of the women and the salaries of the working staff. In addition, we attempted to compute the value of the increased social capital and the reduction of negative occurrences that results from the work done at Inspirations Studio.

\section{Results}

Figure 1 demonstrates the cost structure and revenue streams of Inspirations Studio.

Figure 1. Cost Structure and RevenueStreams

Inspirations Studio

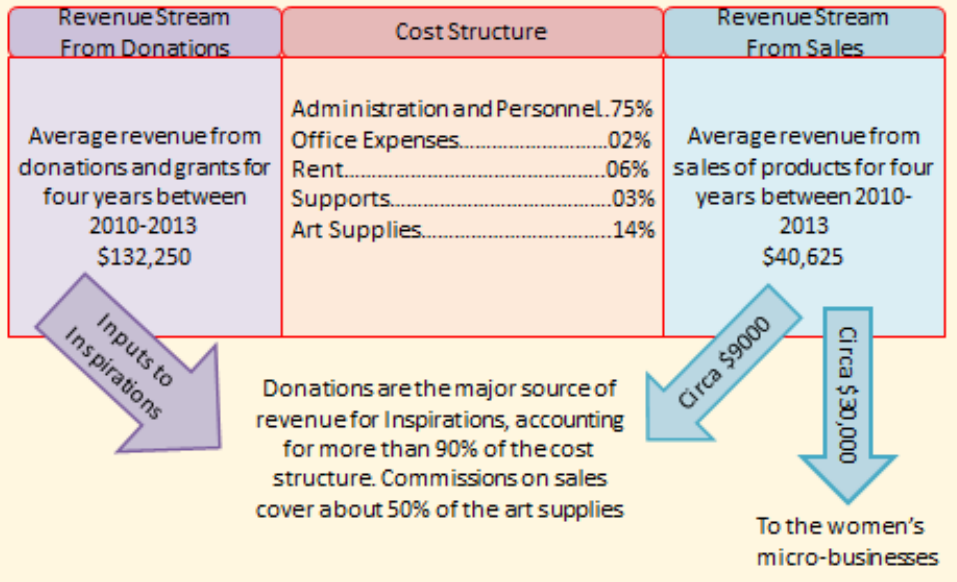

Were this a regular business, the revenue stream from sales should cover all the expenses and provide a surplus as profit. However, as this is a nonprofit social enterprise, the expectations are not necessarily to cover all costs through sales revenue. The purpose of this social enterprise is to provide skills and supports for the potters to create and sell their pottery as part of their own microbusinesses. Thus only about one quarter of the income generated through sales is returned to the studio, the rest stays with the women. All told, the earned income from sales covers less than $10 \%$ of the total costs of running the studio. The question then is: Are the donors' investments getting valued social returns? 


\subsection{Actual Return on Investment}

In order to answer this question we first calculated the financial benefits accrued by the women potters and compared that to the total income from donations. Figure 2 shows the yearly income through donations and sales, and the differences between the two. The annual donations have steadily gone up as Inspirations has acquired new donors. These donations spiked in 2013, the same year that sales took a significant dip. (Both the spike in donations and the dip in sales are attributable to the necessity for Inspirations to move the studio to a new location. The extra donation was to help Inspirations with the move. The move also proved disruptive in terms of production and subsequently had a significant impact on sales. The sales figures for the first three quarters of 2014 have already surpassed the total earnings from 2013, and as with other retail businesses, the majority of sales occur during the pre-Christmas season.) Because of this anomaly, we based our calculations on the four-year average.

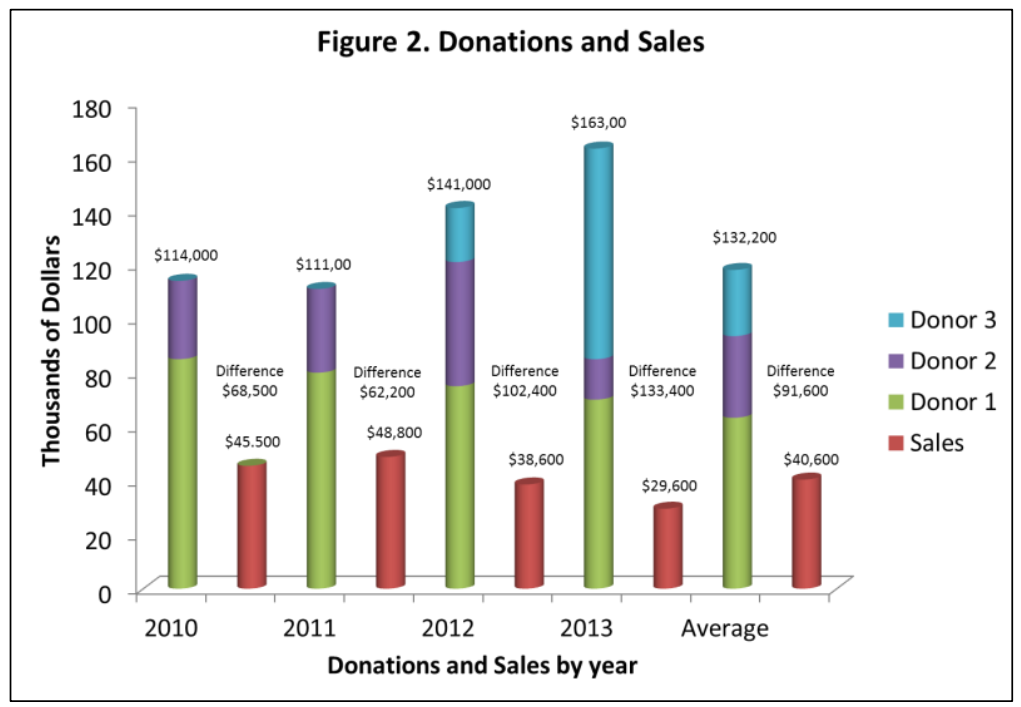

On average, donations accounted for $\$ 132,250$ per year over the four-year period and sales over the same period averaged \$40,625. The difference between sales and donations was \$91,625. In terms of a purely financial return on investment, this constitutes a loss. However, Inspirations Studio is not a commercial enterprise, where the bottom line is purely in terms of financial returns. It is a social enterprise, where the social returns are equal to, or even outweigh, the financial returns.

\subsection{Dollar value of measurable health/social benefits}

As described above, our primary strategy for measuring social return on investment was to record changes in the women's health behaviour and social well-being. We noted some significant changes in their behaviour. Table 1 presents those changes in behaviour and well-being whose impact can be more or less directly measured. The cost savings incurred through decreased food bank use was calculated from figures provided us by the Daily Bread Food Bank (Anderson, October 2104). The cost of a food basket for a family of 4 is $\$ 25 / 2$ weeks. We convert this to $\$ 6 / 2$ 
weeks per individual. This translates into $\$ 780$ a year for the five women who reduced their food bank use. Two women quit smoking; smokers cost Ontario $\$ 8,533$ per smoker per year (The Federal Tobacco Control Strategy, 2011). Two women quitting smoking saves $\$ 17,066 /$ year. Three women decreased their visits to hospital emergency rooms, while two women used these services more often than previously, resulting in a net positive change of one. At the most conservative of estimates, this would add up to perhaps $\$ 300$. An ambulance would add an additional \$240 to the bill, of which all but $\$ 45.00$ are covered by the Ontario Health Insurance Plan (OHIP) (Frequently Asked Questions, n.d.)

\begin{tabular}{|c|c|c|c|c|}
\hline Behaviour & Decrease & Increase & $\begin{array}{c}\text { Net positive } \\
\text { change }\end{array}$ & $\begin{array}{c}\text { Average } \\
\text { savings/year }\end{array}$ \\
\hline $\begin{array}{l}\text { Food bank } \\
\text { use }\end{array}$ & 7 & 2 & 5 & $\begin{array}{c}\$ 6 * 26 * 5= \\
\$ 780\end{array}$ \\
\hline Smoking & 2 & 0 & 2 & $\begin{array}{c}\$ 8,533 * 2= \\
\$ 17,066\end{array}$ \\
\hline \multirow[t]{2}{*}{$\begin{array}{l}\text { Emergency } \\
\text { Services }\end{array}$} & 3 & 2 & 1 & $\begin{array}{c}\$ 148 / \text { day } \\
\text { Ambulance } \\
\$ 400\end{array}$ \\
\hline & Change & No Change & $\begin{array}{l}\text { Net Positive } \\
\text { Change }\end{array}$ & \\
\hline $\begin{array}{l}\text { Increased } \\
\text { physical } \\
\text { activity }\end{array}$ & 2 & 14 & 2 & $\begin{array}{c}\$ 696 * 2=\$ 1 \\
776\end{array}$ \\
\hline $\begin{array}{l}\text { Improved } \\
\text { sleep }\end{array}$ & 6 & 10 & 6 & $?$ \\
\hline $\begin{array}{l}\text { Improved } \\
\text { eating habits }\end{array}$ & 5 & 11 & 5 & $\begin{array}{c}\$ 827 * 5=\$ 4 \\
135\end{array}$ \\
\hline $\begin{array}{l}\text { Healthy } \\
\text { weight }\end{array}$ & 10 & 3 & 10 & $\begin{array}{c}\$ 1,092 * 10= \\
\$ 10,920\end{array}$ \\
\hline
\end{tabular}

The survey also inquired into the women's physical activity, eating habits and healthy weight. Estimating from various sources, yearly savings in health care costs from: a) increased physical activity amounts to $\$ 696$ (adjusted from \$330 in 1987 dollars to 2014 value; CDC, 2000); b) improved eating habits amounts to $\$ 827$ (Sacks, et al., 2009); and c) healthy weight amounts to $\$ 1,092$ calculated as $18.2 \%$ (Public Health Agency of Canada, n.d.) more than the $\$ 6000$ national per capita health costs (Global News, 2013). Adding these together for the women in our sample, this would constitute a total savings of $\$ 16,831$. All of these improved health behaviours taken together generates a $\$ 34,677$ savings for society. This reduces the difference between the costs and benefits to $\$ 56,948$. Dividing this by 28 women, the cost of maintaining Inspirations Studio comes to $\$ 2,034$ per woman. One way of looking at this per woman cost would be as an educational expense. The Toronto and District School Board (TDSB) offers adult education courses in both pottery and business education. The average cost for a nine-week course is approximately \$234 for adult learners (Learn for Life, 2013). Conservatively we might calculate that over 52 weeks, the woman receive the equivalent of 2 nine-week courses. Subtracting this from the \$2,034 would reduce the cost per woman to $\$ 1,566$. Thus the total unaccounted for costs are $\$ 45,684$.

Basically, then, the question becomes whether the community and societal benefits that are not directly translatable to dollars, are worth $\$ 45,684$ layout towards the work Inspirations 
does for the women. The question is a moot one when considering the non-directly measurable benefits to the community.

\subsection{The non-measurable value of social, health and economic benefits}

Tables 2 and 3 present the non-measurable but beneficial changes reported by Inspirations' members.

\begin{tabular}{|l|c|c|c|c|}
\hline Table 2. Non-measurable changes in health \\
\hline Behaviour & Decrease & Increase & $\begin{array}{c}\text { Net positive } \\
\text { change }\end{array}$ & Implications \\
\hline $\begin{array}{l}\text { Substance } \\
\text { use }\end{array}$ & 2 & 0 & 2 & $\begin{array}{c}\text { Decreased } \\
\text { probability of } \\
\text { crime or overdose } \\
\text { and their }\end{array}$ \\
\hline $\begin{array}{l}\text { Seeing a } \\
\text { counsellor }\end{array}$ & 2 & 2 & 0 & \\
\hline \begin{tabular}{l} 
attendant costs \\
\hline Medications
\end{tabular} & 10 & 6 & No Change & $\begin{array}{c}\text { Net Positive } \\
\text { Change }\end{array}$ \\
\hline & & & 10 & $\begin{array}{c}\text { Better controlled } \\
\text { medication leads } \\
\text { to more pro-social } \\
\text { behaviour }\end{array}$ \\
\hline
\end{tabular}

In Table 2 we see a decrease in substance use. Because we could not measure the probability of crime and imprisonment that could accompany use of substances, could not put a dollar value on the reported cessation of substance use. However if this decrease prevented even one incident involving the police, substantial savings would be noted. For example, payment to a legal aid lawyer would amount to \$94.28/hour (Legal Aid Ontario, n.d.). Add to this trial costs, and $\$ 578$ daily imprisonment costs (MacCharles, 2012, Oct. 23), even this modest reduction of substance use could account for significant societal savings.

Table 3 displays eight measures of social and economic well-being that are often related to increased social capital. There are many different ways to understand social capital (DeFillipis, 2001), however, perhaps the best understanding of the concept is contained in the earliest published reference to social capital: "those tangible assets [that] count for most in the daily lives of people: namely goodwill, fellowship, sympathy, and social intercourse among...individuals" (Hanifan, 1916, as cited in OECD insights, accessed 2014-09-05). Social capital provides the individual access to resources that enhances economic (Bourdieu, 1980, as cited in Portes, 1998) and human capital (Coleman, 1988) while at the same time creating a network of trust that enhances the economic capital of the community (Portes, 1988). Several studies have linked high community social capital with crime reduction (e.g. Lederman, Ioayza \& Menendes, 2002; Buonano, Montolia \&Vanin, 2009). 


\section{Table 3. Non-measurable changes in social well-being}

\begin{tabular}{|c|c|c|c|c|}
\hline Behaviour & Change & No change & $\begin{array}{c}\text { Net positive } \\
\text { change }\end{array}$ & Implications \\
\hline $\begin{array}{l}\text { Family } \\
\text { relationships }\end{array}$ & 7 & 7 & 7 & \multirow{6}{*}{$\begin{array}{l}\text { The literature } \\
\text { shows that } \\
\text { improvement in } \\
\text { all of these taken } \\
\text { together leads to } \\
\text { greater social } \\
\text { capital in the } \\
\text { community. } \\
\text { Greater social } \\
\text { capital leads to } \\
\text { lower crime and } \\
\text { its attendant } \\
\text { costs. }\end{array}$} \\
\hline $\begin{array}{l}\text { Relations } \\
\text { with friends }\end{array}$ & 7 & 9 & 7 & \\
\hline New friends & 13 & 2 & 13 & \\
\hline $\begin{array}{l}\text { Improved } \\
\text { outlook }\end{array}$ & 10 & 4 & 10 & \\
\hline $\begin{array}{l}\text { Increased } \\
\text { leisure } \\
\text { activities }\end{array}$ & 8 & 8 & 8 & \\
\hline $\begin{array}{l}\text { Increased } \\
\text { volunteering }\end{array}$ & 9 & 6 & 9 & \\
\hline $\begin{array}{c}\text { Gained } \\
\text { beneficial } \\
\text { new skills }\end{array}$ & 10 & 2 & 10 & $\begin{array}{l}\text { Equivalent cost } \\
\text { per HS course } \\
\$ 200 * 8=\$ 1600\end{array}$ \\
\hline $\begin{array}{l}\text { Increased } \\
\text { buying } \\
\text { power }\end{array}$ & 15 & 1 & 15 & $\begin{array}{c}\text { Hard to measure } \\
\text { the exact dollar } \\
\text { value }\end{array}$ \\
\hline
\end{tabular}

We do not claim that the increased social and human capital of the 29 members of Inspirations has, in itself, a significant impact on their communities, however, we do argue that programs such as Inspirations, which increase social capital, is a benefit to the community and when calculating SROI, this should always be taken into consideration.

In addition to increased individual social capital, as attested to by the women themselves and the consequent increased community social capital, the community also benefits economically from the existence of Inspirations Studio. The women's earned income in terms of increased buying power is spent in the community, mostly for food, according to the survey. Inspirations Studio also provides employment and thus salaries to its regular staff members, which generates financial value to the community. Thus, although it is difficult to attribute and exact value to these economic activities, they do provide a benefit to the community's businesses.

\section{Summary and Conclusions}

Calculating return on investment in a social enterprise is not solely a financial consideration. The value of the social outcomes must also be part of the equation. For Inspirations Studio the financial return on investment fell short of breaking even. The challenge was to determine whether the social benefits accruing from the existence and performance of the studio could account for the financial "loss" which in this case was \$91, 625. With the help of the survey, we were able to determine changes in the women's health and social-well being. For some of these we were able to approximate cost-savings in health care and social welfare. In addition to these savings we also considered the equivalent educational costs of the business and pottery 
instruction the women were receiving. All of these savings and benefits were subtracted from the costs column, thus reducing total costs by half to $\$ 45,684$. In terms of directly measurable costbenefit outcomes, Inspirations enterprise still fell short.

Two things need be mentioned at this point. The first is that we used the most conservative figures for all of our calculations, always choosing the lowest figures when a range was given and always estimating the lowest possible number of events. Thus if we erred in our calculations it was towards underestimating rather than overestimating the impact of Inspirations Studio. The second is that during the study's duration, an unanticipated major change occurred at Inspirations; they were required to move premises. This had an impact on both the funding input, with a one-time increase to cover the moving costs, and the sales output, which was disrupted because of lost productivity time in the studio. Despite the fact that we used a 4-year average, these unanticipated gains and losses skewed the average difference between costs and benefits slightly. Even with these qualifications, the question that remains is whether the non-measurable benefits are worth the monetary input, which translates to the equivalent cost of $\$ 1,566$ per woman member of Inspirations.

One of the most important benefits all enterprises - commercial, professional, governmental and nonprofit - provide to their communities is increased economic input. Inspirations provides permanent salaries for three staff members as well as salaries for experts invited from time to time to instruct the women in business matters and pottery creation. The earnings of the women members of Inspirations provided them with more buying power, as indicated in the survey, and this was spent mainly on food, in local community shops.

In our survey we also noted several behavioural changes that indicated increased individual social and human capital. We offered confirmation from the literature that increased social capital has direct and indirect positive economic impacts on the community. However, since the increased social capital evidenced in the women of Inspirations is but a drop in the ocean, we couldn't argue a direct impact. What we do argue is that programs such as Inspirations and Sistering, taken as an aggregate, definitely would have an impact on the quality of civic life in the community, which in turn has an impact on the economy of the community.

Despite all the measurement difficulties experienced in this study, starting from the retrospective and subjective nature of the questionnaire, to the tenuousness of the proxy measures, and the non-measurable benefits to society, it is still reasonable to conclude that the social return on investment of Inspirations Studio is on the gains side of the column unquestionably for the women members, but also for society as a whole. Financially, a very conservatively calculated net cost of $\$ 1,566$ per member provides far more than that in community benefits, even if these benefits are not directly calculable. 


\section{References}

About Us. (n.d.). Retrieved from http://inspirationsstudio.org/inspirations-studio/December 2014

Anderson, S. Personal communication, October 2104

Bourdieu, P. (1986). The forms of capital. In J. Richardson (Ed.) Handbook of Theory and Research for the Sociology of Education (New York, Greenwood), 241-258.

Buonano,P., Montolia,D. \&Vanin,P. (2009). Does social capital reduce crime? Journal of Law and Economics, 52(1), 145-170. Article DOI: 10.1086/595698

Center for Disease Control. (2000). Retrieved from http://www.cdc.gov/media/pressrel/r2k1006a.htm December 2014.

Coleman, J. (1988). Social Capital In the Creation of Human Capital. The American Journal of Sociology, Vol. 94, Supplement: Organizations and Institutions: Sociological and Economic Approaches to the Analysis of Social Structure (1988)

DeFillipis, J. (2001). The myth of social capital in community development. Housing Policy Debate, 12(4).

Frequently Asked Questions. (n.d.) Retrieved from http://www.torontoems.ca/mainsite/service/faq.html\#Anchor-Why-49425, December 2014

Global News. (2013). Retrieved from http://www.phac-aspc.gc.ca/hp-ps/hl-mvs/oic-oac/indexeng.php, December 2014

Hanifan, L. (1916). As cited in OECD Insights: What is social capital? Retrieved from http://www.oecd.org/insights/37966934.pdf September 2014

Learn for Life. (2013). Retrieved from http://www.tdsb.on.ca/Portals/0/AdultLearners/docs/L4Lfallwebfinal.pdf, October 2014.

Lederman,D., Loayza, N. \& Menendez, A.M.( 2002). Violent crime: Does social capital matter? Economic Development and Cultural Change, 50(3), 509-539. Retrieved from Article DOI: $10.1086 / 342422$

Legal Aid Ontario. (n.d.). Retrieved from http://www.legalaid.on.ca/en/info/tariff_billing.asp

MacCharles, T. (2012, October 23). Federal Prison Population in Canada Growing. The Toronto

Star. Retrieved from

http://www.thestar.com/news/canada/2012/10/23/federal_prison_population_in_canada_growing. $\underline{\mathrm{html}}$ 
Meinhard, A., Lok, A. \& O’Connor, P. (2014 - forthcoming). "Inspirations Studio at Sistering: A systems analysis.” In J. Quarter, S. Ryan (Eds.) Business Done Differently. University of Toronto Press.

Portes, A. (1998). Social capital: Origins and applications. Annual Review of Sociology, 24:1-24.

Public Health Agency of Canada. (n.d.). Obesity in Canada. Retrieved from http://www.phacaspc.gc.ca/hp-ps/hl-mvs/oic-oac/index-eng.php

Sacks, N., Cabral, H., Kazis, L. E., Jarrett, K. M., Vetter, D., Richmond, R., \& Moore, T. J. (2009). A web-based nutrition program reduces health care costs in employees with cardiac risk factors: Before and after cost analysis. Journal of Medical Internet Research, 11(4), e43. DOI:10.2196/jmir.1263

The Federal Tobacco Control Strategy. (2011). Retrieved from http://www.smokefree.ca/pdf_1/2011/the\%20cost\%20of\%20failure.pdf , December 2014. 